\title{
What do "do" verbs do? The semantic diversity of generalised action verbs.
}

Link to publication record in Manchester Research Explorer

\section{Citation for published version (APA):}

Schultze-Berndt, E. (2008). What do "do" verbs do? The semantic diversity of generalised action verbs. In E. Verhoeven, S. Skopeteas, Y-M. Shin, Y. Nishina, \& J. Helmbrecht (Eds.), Studies on grammaticalization (pp. 185208). de Gruyter, Walter GmbH \& Co.

\section{Published in:}

Studies on grammaticalization

\section{Citing this paper}

Please note that where the full-text provided on Manchester Research Explorer is the Author Accepted Manuscript or Proof version this may differ from the final Published version. If citing, it is advised that you check and use the publisher's definitive version.

\section{General rights}

Copyright and moral rights for the publications made accessible in the Research Explorer are retained by the authors and/or other copyright owners and it is a condition of accessing publications that users recognise and abide by the legal requirements associated with these rights.

\section{Takedown policy}

If you believe that this document breaches copyright please refer to the University of Manchester's Takedown Procedures [http://man.ac.uk/04Y6Bo] or contact uml.scholarlycommunications@manchester.ac.uk providing relevant details, so we can investigate your claim.

\section{OPEN ACCESS}


Ebert, Karen $\mathrm{H}$

2000 Aspect in Maltese. In Tense and Aspect in the Languages of Europe, Östen Dahl (ed.), 753-785. Berlin: Mouton de Gruyter.

Fabri, Ray

1995 The tense and aspect system of Maltese. In Tense Systems in European Languages, Rolf Thieroff and Joachim Ballweg (eds.), Vol. II, 327-343. Tübingen: Niemeyer.

Heine, Bernd

1993 Auxiliaries. Cognitive Forces and Grammaticalization. Oxford: Oxford University Press.

Heine, Bernd, and Tania Kuteva

2002 World Lexicon of Grammaticalization. Cambridge: Cambridge University Press.

Lehmann, Christian

1989 Grammatikalisierung und Lexikalisierung. Zeitschrift für Phonetik, Sprachwissenschaft und Kommunikationsforschung 42 (1): 11-19.

1991 Strategien der Situationsperspektion. Sprachwissenschaft 16 (1): 1-26.

1995 Thoughts on Grammaticalization. München: LINCOM Europa.

2002 New reflections on grammaticalization and lexicalization. In $\mathrm{New}$ Reflections on Grammaticalization, Ilse Wischer and Gabriele Diewald (eds.), 1-18. Amsterdam: John Benjamins.

2005 Wortarten und Grammatikalisierung. In Wortarten und Grammatikalisierung. Perspektiven in System und Erwerb, Clemens Knobloch and Burkhard Schaeder (eds.), 1-20. Berlin: de Gruyter.

2006 Les role sémantiques comme prédicats. Bulletin de la Société de Linguistique de Paris 101 (1), 67-88.

Spagnolo, Michael

$2007 \quad$ L-aspett lessikali fil-verb Malti. Dissertazzjoni mressqa lill-Istitut talLingwistika, 1-Università ta' Malta, ghall-grad ta' Masters fl-Arti M.A. - fil-Lingwistika.

Stolz, Thomas, and Andreas Ammann

forthc. Beda u Oabad: The Maltese Inchoative/Ingressive. Romano-Arabica. Special Issue on Peripheral Arabic Dialects. University of Bucharest: Center for Arab Studies.

Vanhove, Martine

1991 La langue maltaise. Etudes syntaxiques d'un dialecte arabe «périphérique». Wiesbaden: Harrassowitz.

Van Pottelberge, Jeroen

2005 Ist jedes grammatische Verfahren Ergebnis eines Grammatikalisierungsprozesses? Fragen zur Entwicklung des am-Progressivs. In Grammatikalisierung im Deutschen, Thorsten Leuschner, Tanja Mortelmans, and Sarah De Groodt (eds.), 169-192. Berlin: de Gruyter.

\section{What do "do" verbs do?}

The semantic diversity of generalised action verbs

\section{Eva Schultze-Berndt}

\section{Introduction}

All languages seem to have one or more verbs which, like $d o$ in the English translations of (1) to (4) below, are used as 'pro-verbs' in contexts where the nature of an event is unknown or left unspecified, and represented by a pronominal or interrogative complement - most frequently a noun phrase, but possibly, as in the Jaminjung example, an interrogative "preverb". Following Van Valin and LaPolla (1997), verbs of this nature will be referred to as 'generalised action verbs' (or GAV for short) in this paper, interchangeably with 'do-verbs'.

(1) Samoan

'o aa lua mea e fai taeao?

PRES what 2DU thing.PL FUT do tomorrow

'what are you two going to do tomorrow?' (lit. 'what are your things to be done tomorrow?') (Mosel and Hovdhaugen 1992: 520)

\section{(2) Jaminjung}

warndug $=$ biya $\quad$ yurru-wu-yu,

do. what=now IPL.INCL $>3$ SG-POT-do

'what are we going to do now (... are we going to camp out?)'

(Schultze-Berndt, own fieldwork)

\section{(3) Kalam}

tap tmey g-pay

thing bad do-3PL.PST

'they have done bad things.' (Pawley 1994: 408) 
(4) Ewe

$$
\begin{array}{lll}
\text { ao, } & \text { nye-mé-wo-e } & o \\
\text { no } 1 \mathrm{SG}-\mathrm{NEG} \text {-do-3SG } & \mathrm{NEG}
\end{array}
$$

'no, I didn't do it' (Ameka 1994: 72)

It has been claimed in the literature that the concept ' $\mathrm{DO}$ ' is universal, and moreover, that it is universally linked to the notion of agency (see e.g. Goddard and Wierzbicka 1994: 42-43, Dowty 1979: 110-125). This equation of 'DO' with agency is at the heart of proposals to use DO in the semantic decomposition of verbs, that is, in defining the meaning of verbs by means of supposedly semantically primitive concepts. According to a related line of argument (Foley and Van Valin 1984: 47-53, Van Valin and LaPolla 1997: 102-129), an underlying DO operator is said to define Vendlerian activity predicates, i.e. those depicting continuous, atelic events. Activity predicates may be agentive, such as walk, sing or dance in English, or non-agentive roll, rain or cry (in the reading of involuntary crying).

However, if one examines the meaning and functions of generalised action verbs cross-linguistically, it becomes clear that they are not necessarily restricted to expressing either agency or activity. Thus, the verbs that translate as 'do' in (1) to (4) above actually cover a wide semantic area ranging from causation to manifestation of a quality, inchoativity, verbaliser with sound-symbolic elements, and quotation marker. In this paper, I will argue that these different uses are related, and that the semantic domains potentially covered by 'do' verbs can be arranged in the form of a semantic map. While some of the uses are linked by the semantic components of agentivity, causation or activity, others may better be accounted for by a semantic component of internal causation or "manifestation". Diagnostics for the different uses of 'do' verbs are their morphosyntactic valency, different selectional restrictions on their "subject" participant, and the semantics of the predicative complement expression accompanying them.

This semantic diversity of 'do' verbs also has implications for their place in grammaticalisation theory. While the grammaticalisation of 'do' verbs in some well-described languages (particularly English $d o$ ) has been the subject of considerable study and controversy (see van der Auwera and Genee 2002 for a recent concise overview), more general accounts of the development of 'do' verbs are noticeably absent from the literature on grammaticalisation, even from works devoted to the development of auxiliaries such as Heine (1993), Kuteva (2001), and Anderson (2006). Where the grammaticalisation of 'do' verbs is discussed, the focus is on the result, i.e. the grammatical functions fulfilled, rather than on possible paths of development. For example, Lehmann (1995: 31-32, 115) mentions the use of 'do' verbs in constructions expressing habituality, predicate focus, predicate topicalisation, and emphasis. Heine and Kuteva (2002: 117-120) list five possible developments of a verb meaning 'DO' (which incidentally they equate with 'MAKE'): causative, progressive marker, emphasis marker, obligation marker, and pro-verb (or "semantically empty predicate marker"). Anderson (2006: 357-358) gives examples of 'do' verbs occurring in periphrastic constructions for future as well as past tense, and habitual aspect. Jäger (2006: 268-294), the most extensive survey of grammatical functions of 'do' periphrasis, provides a seemingly heterogeneous list of functions which include intensive/emphatic marking, past and future tense, desiderative and conative modality, progressive and habitual aspect, but also completive aspect. He also mentions inchoative marking as a "rare type of periphrastic aspect" marked by a 'do' verb (2006: 276).

All of these authors treat 'do' verbs as a semantically uniform category, e.g. of "schematic action" (Jäger 2006: 29); similarly, "do' as a source of grammaticalisation simply gets subsumed under the "Action Scheme" by Heine (1993: 28, 34f.) and Anderson (2006: 358). While it is beyond the scope of this paper to explore the evidence for the development of generalised action verbs in grammaticalisation, the findings in this paper suggest that it may well be worth looking more closely at the semantic range of the lexical 'do' verbs, given that these differ considerably cross-linguistically. This might go some way towards explaining the heterogeneity of grammatical functions expressed by these verbs, since the lexical semantics of the verb may actually provide starting points for different grammaticalisation paths. For example, the causative function seems to depend on the presence of a "creation" sense of the lexical verb (Section 2.1). The use of some 'do' verbs in constructions ascribing a physical or emotional condition to an experiencer (i.e. in the sense of 'feel', Section 2.4.2) makes a development to a desiderative marker more plausible. Even an inchoative function can be found for non-periphrastic uses of 'do' verbs in some languages (Section 2.4.4).

The findings presented here are tentative in the sense that they are based on a small, but genetically and areally diverse, convenience sample of languages where 'do' verbs exhibit a particularly interesting range of uses, and for which fairly explicit descriptions of the uses of the verb(s) in 
question and/or texts are available. The languages investigated here (in addition to English and German) and the sources used are listed in Table 1. $:$

Table 1. Language sample on which this study is based

\begin{tabular}{|c|c|c|}
\hline Language & Affiliation & Sources \\
\hline Samoan & $\begin{array}{l}\text { Polynesian, Oceanic, Aus- } \\
\text { tronesian }\end{array}$ & $\begin{array}{l}\text { Mosel and Hovdhaugen 1992; } \\
\text { Mosel } 1994\end{array}$ \\
\hline Kalam & $\begin{array}{l}\text { Kalam, Trans-New Guinea } \\
\text { (Papuan) }\end{array}$ & Pawley 1993,1994, n.d. \\
\hline Yimas & Sepik-Ramu (Papuan) & Foley 1991 \\
\hline Jaminjung & $\begin{array}{l}\text { Western Mindi, Non-Pama- } \\
\text { Nyungan (Australia) }\end{array}$ & $\begin{array}{l}\text { own fieldwork; Schultze-Berndt } \\
2000\end{array}$ \\
\hline Ewe & Gbe, Kwa, Niger-Congo & Ameka 1994; Essegbey 1999 \\
\hline Hausa & Chadic, Afro-Asiatic & Jaggar 2001; Newman 2000 \\
\hline Kham & $\begin{array}{l}\text { Khamish, Tibeto-Burman, } \\
\text { Sino-Tibetan }\end{array}$ & Watters 2002 \\
\hline Chantyal & $\begin{array}{l}\text { Tibetic, Tibeto-Burman, Sino- } \\
\text { Tibetan }\end{array}$ & $\begin{array}{l}\text { Noonan } 1999,2001 \text {; Noonan } \\
\text { and Grunow-Harsta } 2002\end{array}$ \\
\hline
\end{tabular}

All the 'do' verbs in the sample have the function of generalised action verb illustrated in (1) to (4). Their other functions will be surveyed in Section 2 of this paper. In Section 3, I summarise the range of functions of generalised action verbs in the form of a semantic map and will return to the question of implications for grammaticalisation.

\section{Functions of 'do' verbs in a cross-linguistic perspective}

This section summarizes the main, recurring uses of generalised action verbs found in the languages surveyed. For convenience of exposition, the uses are divided into four major categories: causative verbs (section 2.1), activity verbs (section 2.2), mimetic verbs (section 2.3 ) and verbs of internal causation (2.4). It should be kept in mind though that it is the rule rather than the exception that a 'do' verb in a given language has more than one of these uses, and that the boundaries between uses are not always clear-cut (see also Section 3).

\subsection{Causative verb}

\subsubsection{Verb of manufacturing or creation (CREATE)}

Verbs used as generalised action verbs often have a - presumably more basic - meaning of "creation" or "manufacturing", i.e. a meaning close to English make. They have two participants, one of which is a true Agent (in the sense that the creation semantics presupposes agentivity and control). The other participant is an entity brought into existence ('Effected Theme'). Languages with verbs of this nature are not hard to find. They include German (machen) and French (faire) as well as the majority of languages in our sample (all in fact with the exception of Jaminjung). Examples from Samoan and Kalam are included here for illustration.

(5)

Samoan

... fai se kakou pe'epe'e

do NSPEC.SG 1PL.INCL cream

'make some cream for us' (lit. 'make some of our cream') (Mosel and Hovdhaugen 1992: 771)

(6) Kalam

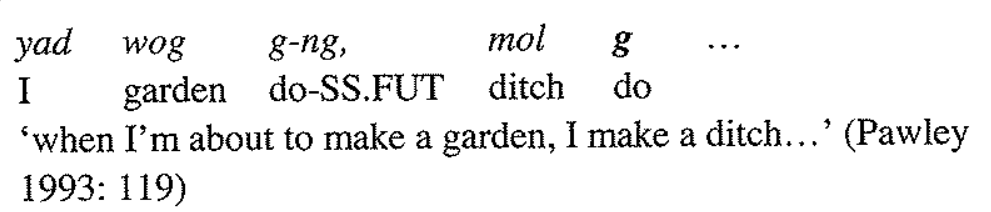

\subsubsection{Productive causative marker (CAUSE)}

It is well known that generalised action verbs are also used in many languages in a more grammaticalised function, i.e. as productive markers in periphrastic causative expressions (see e.g. van der Auwera 1999). Again, French faire is a well-known example; languages in the sample displaying this use of 'do' verbs are Ewe and Chantyal. 


\section{(7) Ewe}

$\begin{array}{llllll}\text { tsidzadza } & \text { lá } & \text { wo-e } & \text { bé } & \text { me-tsí megbé } \\ \text { rain } & \text { DEF } & \text { DO-3SG.DO COMP } & \text { 1SG-remain back }\end{array}$

'The rain made it that I was late', 'The rain caused me to be late' (Ameka 1994: 71)

\section{(8) Chantyal}

\section{Ram-sa nāni-ra yep-ñ. la $a$-i}

Ram-ERG baby-DAT stand-RES do-PF

'Ram stood the baby up' (lit. 'Ram caused the baby to stand')

(Noonan and Grunow-Harsta 2002: 83)

Semantically, the causative function differs from the creation function and the GAV function in allowing for the expression of a caused event with a second participant, the Causee.

\subsection{Activity verb (ACTIVITY)}

According to the literature, a typical function of generalised action verbs is their use as verbaliser in phrasal predicates denoting an activity or accomplishment involving a controlling agent, with a non-finite verb, a deverbal noun or any other nonverbal event expression as a complement. This use, in so far as it is regarded as overtly reflecting the decompositional structure of the predicate in question, forms one of the bases for claims about the agentive nature of 'do'. Indo-Aryan and Iranian languages and Japanese are well-known examples of languages possessing a large number of complex predicates of this type. They are also found in almost all languages of the sample (though data are too scarce for Yimas and Kham), but Hausa is a language where they abound. The complement of the Hausa verb yi 'do' in these expressions is described as a 'dynamic noun' - presumably meaning a nominal describing an event - by both Jaggar (2001: 430) and Newman (2000: 434).
(9)

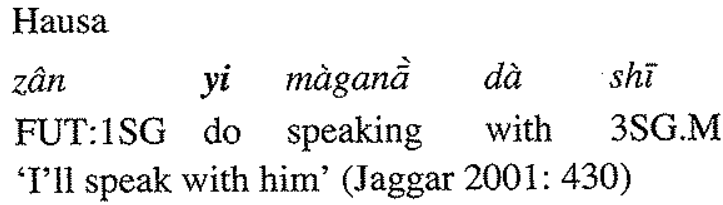

(10) Hausa

$\begin{array}{lllll}t \bar{a} & y i & \text { wà } & \text { mijìntà } & \text { wà̀ts } \bar{l} \\ \text { 3SG.F.PFV } & \text { do } & \text { to } & \text { husband:3SG.F.POSS } & \text { throwing }\end{array}$

\section{dà käyansà}

with thing:3SG.M.POSS

'she threw out her husband's things' (lit. 'she did to her husband throwing with his things') (Jaggar 2001: 435)

"Agentive" activities of the type discussed here need to be distinguished (as Van Valin and LaPolla 1997 do by the use of two different operators, do' and DO) from non-agentive expressions which may qualify as activities in the Vendlerian sense. Examples of the latter are expressions of involuntary internal motion ("tremble'), sound emission ("crack') or light emission ('glitter'). These are subsumed here under the 'exhibit property, manifest' use (see Section 2.4.3), and also the 'ideophone' use (see section 2.3.2), since in many languages, both non-agentive and agentive activities (such as manner of motion) are expressed by sound-symbolic elements, often in combination with generalised action verbs.

\subsection{Mimetic verb}

The term "mimetic verb" is used here, following Güldemann (2001), to cover two important uses of generalised action verbs, the use as quotative verb and the use as verbaliser with sound-symbolic elements.

\subsubsection{Quotative verb (QUOT)}

Generalised action verbs that are also used to introduce quotations are quite common cross-linguistically. Examples can be found in Northern Australian languages (cf. Rumsey 1990, 1994; McGregor 1994), in a num- 
ber of Papuan languages (Foley 1986: 119), and in African languages (Güldemann 2001: 237-245). In this use, the second participant of the 'do' verb, corresponding to the event brought about or to the effected theme, is a quotation. This use of generalised action verbs has been linked to the absence of both a linguistic and a cultural distinction between use of language and other types of behaviour (Rumsey 1990). In other words, speaking can be regarded as just another form of bringing about or 'doing' something. Languages may differ in whether only verbal quotations, i.e. direct speech, can fill the "quotation" slot, or whether reported thought or representation of (non-linguistic) sound can also be treated as a quotation (see section 2.3.2). In some languages, the verb may also take a nominal complement meaning e.g. 'speech', 'word', or 'language'; this is the case e.g. for Samoan fai 'do' (Mosel and Hovdhaugen 1992: 672; Mosel 1994: 335336). For simplicity's sake, only the reported speech function is considered here; this is illustrated with examples from Jaminjung and Samoan.

(11) Jaminjung

"ba-rum" gani-yu=nu

IMP-come 3SG $>3$ SG-do=3SG.OBL

"'come" she said (lit. she did) to him"

(12) Samoan

$$
\begin{aligned}
& \text { fai atu loa le tamaloa 'o } \quad \text { Saetane: } \\
& \text { do DIR then DEF man PRES S. } \\
& \text { "Saefafine, 'ole'a 'e fa'atali atu..." } \\
& \text { S. FUT 2.SG wait DIR } \\
& \text { 'Then the man Saetane said: "Saefafine, wait..." (Mosel and } \\
& \text { Hovdhaugen 1992: 672) }
\end{aligned}
$$

In many language descriptions, a generalised action verb in this use is assigned a separate sense of 'say'; this also forms the basis for many claims about the grammaticalisation of a verb 'say' as a quotation marker. However, as Güldemann $(2001,2000)$ has argued in convincing detail, lexical speech verbs are only one possible source of quotative markers. Manner deictics ('thus'), similative markers ('like') and, as demonstrated here, generalised action verbs may all function as quotative markers and may undergo further grammaticalisation to general complementisers not re- stricted to reported speech and to markers of hearsay evidentiality (see in particular Güldemann 2002: 283).

\subsubsection{Verbaliser with sound-symbolic expressions (IDEO)}

Another function of 'do' verbs, which is at least as common as their quotative use, is their use as a verbaliser with sound-symbolic elements (variously termed 'onomatopoeia', 'ideophones' or 'sound-symbolic adverbs'). Although these two uses are not necessarily correlated (i.e. do not always co-exist in the same language), it has been proposed that they may be linked in that "an ideophone might be considered a word in quotation marks" (Samarin 1971: 150, attributed to A. Meeussen, cf. also Cohen et al. 2002: 247).

Sound-symbolic elements are often, but not necessarily, iconic representations of noises. Cross-linguistically, they also frequently denote manner of motion (see examples (13) and (14)) and other activities, but also shape, texture or colour, which links them not only to the domain of activity verbs discussed in section 2.2 , but also to the domain of verbs of internal causation which is the topic of section 2.4 below.

In terms of their syntactic behaviour, sound-symbolic elements are not always exclusively linked to 'do' verbs, but can often be used adverbially with other semantically appropriate verbs (or nouns), e.g. verbs of motion. Chantyal and Hausa are examples of languages where this option exists (see the interchange in (13)), but there is a tendency for sound-symbolic elements to combine with 'do' verbs in a conjoined structure with the (semantically) main predicate.

(13) Chantyal

$$
\begin{aligned}
& \text { A: kharakhara bfii-ro! - B: ca kharakhara la-i } \\
& \text { steadily say-IMP that steadily do-PFV }
\end{aligned}
$$$$
\text { A: "continue talking!" - B: "I'll keep on (talking)" (Noonan 1999: }
$$$$
\text { 588) }
$$ 
(14)

Hausa

$\begin{array}{llllll}t \tilde{a} & y i & \text { wup } & t \vec{a} & \text { kaam } \grave{a} & \text { shi } \\ \text { 3SG.F } & \text { do } & \text { (IDEOPHONE) } & \text { 3SG.F } & \text { catch } & \text { 3SG.M }\end{array}$

'she grabbed him in a flash' (lit. 'she did wup she caught him')

(Newman 2000: 474)

A generalised action verb may also be used to incorporate non-verbal mimetic expressions - i.e. gestures - into speech (also included in the domain of mimesis by Güldemann 2001). This use has been left out of consideration here because information in the literature is regrettably scarce.

A further frequent function of generalised action verbs, is that of verbaliser with loanwords; this has been recognised as one of the important functions of 'do' verbs in the literature, related to the observation that the borrowing of verbs as verbs is cross-linguistically marked (Moravcsik 1975, van der Auwera 1999, Jäger 2004, Wichman and Wohlgemuth 2005, Muysken 2000: 184-220). This is linked to the functional domain of quotations and ideophonic expressions by Cohen et al. (2002: 247) because of the "expressive nature of ... a loanword" and because "[q]uoting is equivalent to posing an item as existing in the language". For reasons of space, this function will be left out of consideration here.

\subsection{Verb of internal causation}

The functions of generalised action verbs reviewed so far - creation verb or causative verb, verbaliser with activity predicates, and mimetic verb already manifest considerable diversity but are still compatible with the presumably prototypical association of 'do' verbs with agentivity. How ever, as already indicated in the introduction, generalised action verbs are not always agentive in nature. Rather, they may be used to predicate events that occur without the involvement of an agent, and also emotional conditions, qualities, conditions or states, and even state changes. It will be argued here that these uses can be subsumed under a general notion of 'internal causation', which however has to be distinguished from agentivity (or activity).

\subsubsection{HAPPEN}

Generalised action verbs in various languages have uses in which they are best paraphrased as 'happen'. In this case, there is no Agent participant; rather, the first participant ("subject") of the verb is an event, which is depicted as coming about without any apparent cause. The resulting expression may be intransitive as in (15), or transitive, if a participant affected by the event can be added as a complement of the verb as in (16).

$$
\begin{array}{lllllllll}
m \tilde{n} a b & n b & a k & n e d & \text { wagn } & a k & \boldsymbol{g} & \text { g-ek } & \ldots \\
\text { country } & \text { such this } & \text { first } & \text { origin } & \text { DEF } & \text { do } & \text { do-3SG.PST }
\end{array}
$$
'the place where this originally happened...' (Pawley 1994: 408)

(16) Ewe

$$
\begin{aligned}
& N u ́ \quad \text { véví wo Kofi (...) } \\
& \text { thing serious do Kofi } \\
& \text { 'something serious happened to Kofi', 'Kofi got injured' (lit. } \\
& \text { 'something serious did Kofi') (Essegbey 1999: 90) }
\end{aligned}
$$

I subsume here under the 'happen' use occurrences of a generalised action verb in impersonal constructions. In languages like Kalam, this type of construction is the main means of conveying a physical or emotional condition. English translations often involve a verb like 'feel', as illustrated in (17). This is however misleading, in that unlike with English feel and the cases discussed in Section 2.4.2, the experiencer is the object, not the subject in this construction.

(17) Kalam

$$
\text { yp tap } \quad \text { g-p }
$$

1SG.OBJ sickness do-PRS

'I feel/am sick' (lit. 'sickness works/happens on me') (Pawley 1994: 397) 


\subsubsection{FEEL}

- In a number of languages, 'do' verbs can function as true equivalents of 'feel'. For example, the generalised action verb $t i$ in the Papuan language Yimas not only has an impersonal use similar to that illustrated in (17) for Kalam to convey a physical or emotional condition (see Foley 1991: 301 for examples), but at least in some complex expressions denoting an experience or desire, the experiencer is the subject.

(18) Yimas

$$
\begin{array}{ll}
\text { nay, ama tpuk am-t-wampuy } & \text { ama-na-tækia-k } \\
\text { Mo 1SG sago.dish eat-NFIN-desire } & \begin{array}{l}
\text { 1SG.SBJ-DEF-do- } \\
\text { do.at.night-IRR }
\end{array} \\
\text { 'Mama, I feel like eating sago' (Foley 1991: 472, 1. 79). }
\end{array}
$$

Another example is Jaminjung, where the verb -yunggu forms complex predicates with non-inflecting predicates ("preverbs") expressing emotional or physical condition of animates, as shown in (19).

\section{(19) Jaminjung}

$$
\begin{aligned}
& \text { yarl / butharl } \quad \text { nga-yunggu-m } \\
& \text { itchy / sad } \quad \text { 1SG }>3 \text { SG-do-PRS } \\
& \text { 'I am/feel itchy / sad' (lit. 'I do itchy / sad') }
\end{aligned}
$$

In Hausa, too, complex predicates formed with $y i$ 'do' not only express activities (see (9) and (10)), but also emotions such as 'being angry', 'being jealous', 'being sad', 'being happy', 'feeling regret', or 'feeling desire', with the experiencer as subject. In many of these cases however $y i$ is interchangeable with a more specific verb $j i$ 'feel' (Jaggar 2001: 430-432).

\subsection{3. 'exhibit PROPERTY'}

Whereas the 'feel' use described in the previous subsection at least requires an animate participant, some languages even possess 'do' verbs which may appear with a complement referring to a substance or a property predicated of an inanimate participant. In this case, the verb may have to be translated with a copular verb 'be' in languages like English and German. An example of a verb with this range of uses is Ewe wo 'do', illustrated in (20).

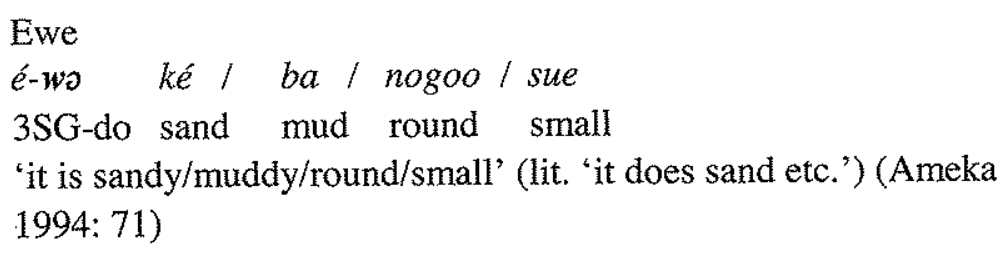

A very similar use of the 'do' verb is also found in Hausa, e.g. in expressions of temperature or weight (Newman 2000: 474, Jaggar 2001: 430).

\subsection{4. 'turn into, become' (INCHO)}

In a number of languages, including in this sample Samoan (Mosel and Hovdhaugen 1992: 113), Yimas (Foley 1991: 293-300) and Jaminjung, the generalised action verb can also translate as 'become', that is, function as an inchoative verb which encodes the transition, of an animate or inanimate, into a state or the transformation into a different entity, with a stative predicate or nominal as complement. From the point of view of theories associating 'do' with agentivity and control, this is of course a rather undesirable phenomenon. Two examples from Jaminjung are (21) and (22).

(21) Jaminjung

$\begin{array}{ll}\text { wurrguru } & \text { nganthu-wu-yu } \\ \text { devil } & \text { 2SG }>3 \text { SG-POT-do }\end{array}$

'you will turn into a devil'

(22) Jaminjung

$\begin{array}{ll}\text { manyirri } & \text { gan-unggu-m } \\ \text { cool } & \text { 3SG }>3 \text { SG-do-PRS }\end{array}$

'it gets cool' (i.e. mild; of yam species after rinsing it and burying it for a few days) 
I will now argue that the notion of 'internal causation' may help to account for all of the uses of 'do' verbs discussed in this section, i.e. the 'happen' use, the 'feel' use, the 'exhibit property', and the inchoative use.

\subsubsection{The notion of internal causation}

The term "internal causation" is introduced by Levin and Rappaport Hovav $(1994,1995)$ to account for the argument structure properties of a subclass of English verbs. They note that the notion of internal causation subsumes agency but goes beyond it, in that verbs like tremble or glitter, with nonagentive or inanimate arguments, can nevertheless describe

internally caused eventualities in the sense that these eventualities are con ceptualised as arising from inherent properties of their arguments (Levin and Rappaport Hovav 1995: 91)

Thus, verbs of internal causation are neutral with respect to agentivity or control. Rather, they attribute to a participant the manifestation of an event, a state change, a quality, or a condition which is not construed as externally caused, but as corresponding to an inherent property of this participant. For example, the verb -yungg $u$ in Jaminjung is indeed restricted to internally caused state changes, e.g. 'become big' = 'grow', 'become mild', 'become night', or 'turn into a devil'. State changes like 'break' or 'open' - corresponding to what Levin and Rappaport Hovav (1995) term externally caused state changes - are encoded in Jaminjung by complex verbs which are not formed with $-y u(n g g u)$, but with the verb -ijga 'go' in a secondary sense of change of state (for details see Schultze-Berndt 2000: Ch. 5). With this restriction of the term 'inchoative' in mind, the difference between the 'inchoative' and the 'manifestation of a condition' reading of $-y u(n g g u)$ 'do', discussed in subsection 2.4.3, may be attributed to differences between the predicative elements that the verb combines with. The two functions are thus closely related. The 'inchoative' reading arises with nominal predicates and stative predicates: here $-y u(n g g u)$ contrasts with the verb - yu 'be' which is used to form stative rather than inchoative expressions with the same predicates. Predicates of bodily and emotional condition, such as yarl 'itchy' or butharl 'sad', on the other hand, generally only combine with $-y u(n g g u)$ and not with $-y u$ 'be', and therefore have to be regarded not as stative, but as dynamic predicates. Consequently, there is no way to express a difference e.g. between "inchoative" 'I am getting itchy' and "stative" 'I am itchy'.

Although the evidence is currently not conclusive, I would like to suggest that 'do' verbs may be used to predicate a condition or property of a participant precisely in the case that it is an inherent property, i.e. not a state resulting from manipulation, but nevertheless externally manifested and relevant. This holds for the examples discussed in subsection 2.4.3.

The analysis in terms of internal causation can probably also apply to most cases where a generalised action verb is claimed to have a reading of 'feel', as in languages mentioned in subsection 2.4.2 above. Possibly, English feel is not an appropriate translation equivalent in these cases either because this verb ascribes an experience to the participant, while the generalised action verb focuses on the manifestation of the condition in the participant. At least for Jaminjung, there is evidence (summarised in Schultze-Berndt 2000: 461-462) that physical or emotional conditions are not ascribed to a non-speaker unless the speaker has some behaviourally manifested evidence for this, such as lively behaviour for happiness.

Finally, the 'happen' use (subsection 2.4.1) is also covered by an analysis in terms of internal causation, since here, an event spontaneously occurs without the involvement of an external Effector or Causer.

The analysis proposed here is supported by those authors who have not limited themselves to listing translation equivalents such as 'do', 'say', 'feel', or 'happen' for a given 'do' verb. A very poignant characterisation is offered by Langdon (1977) for corresponding verbs in Yuman languages of California. These verbs, glossed as 'say', occur in construction with sound-symbolic elements from the semantic domains of noise, motion, emotion, pattern, consistency and shape - i.e. they have a semantic range very similar to that described here for generalised action verbs. Langdon suggests that the relevant construction can be characterised as

descriptive of a characteristic configuration of an individual, object, or situation by focusing on the overt immediately verifiable evidence, while disclaiming any active, deliberate, or volitional intent. (Langdon 1977: 7)

The Yuman examples, as well as the range of uses of 'do' verbs in some languages in our sample, also point to a close link between the uses subsumed here under internal causation, on the one hand, and quotative and ideophone constructions, on the other hand. 


\section{A tentative semantic map}

- In the case of verbs with such general meanings and wide ranges of functions as generalised action verbs, a semantic approach based on paraphrases (such as 'manifestation of an event') is clearly limited. Even more problematic is an approach in terms of decomposition since, as we have seen above, the verbs in question may themselves have as translation equivalents more than one of the supposed semantic primitives CAUSE, BECOME, DO, or HAPPEN which are currently used in decompositional approaches. Rather, the meaning of a semantically general verb can be approached, first, by carefully listing the syntactic environments that it can occur in, and second, by exploring its collocational potential, i.e. its potential to combine with other lexical items, e.g. in complex predicate formation. Its range of uses also depends on its degree of grammaticalisation and on the nature of the verb system in the language (in a language with a closed class of verbs, such as Jaminjung or Kalam, each of them, including the verb used as generalised action verb, is likely to have a wider range of functions than in a language with an open class of verbs).

By comparing the range of functions of corresponding verbs in a number of languages, it is possible to come up with a network of functions, some of which are more closely related than others. Thus, if we find that a single verb never has two specific functions $\mathrm{A}$ and $\mathrm{C}$ unless it also has an additional function $\mathrm{B}$, we can state that $\mathrm{A}$ and $\mathrm{C}$ are more distantly related, and $B$ is an intermediate function in the network. By this method, it is possible to develop a "semantic map" with predictive value (cf. van der Auwera and Plungian 1998, Haspelmath 2003, van der Auwera and Temürcü 2006). A first - and tentative - outline of what such a semantic map might look like for generalised action verbs is provided in Figure 1. For reasons of space and readability, only six languages are represented in the map. The full information on the uses of 'do' verbs in all nine languages (which is compatible with the map as proposed here) is provided in Table 2.

Since it is based on a small sample, the map represents proximities in "semantic space" rather than definite links between individual uses. The "generalised action verb" use is placed in the centre of the map not because it is claimed here that this is the central or basic function of 'do' verbs, but because it was used as a defining criterion to select the verbs.

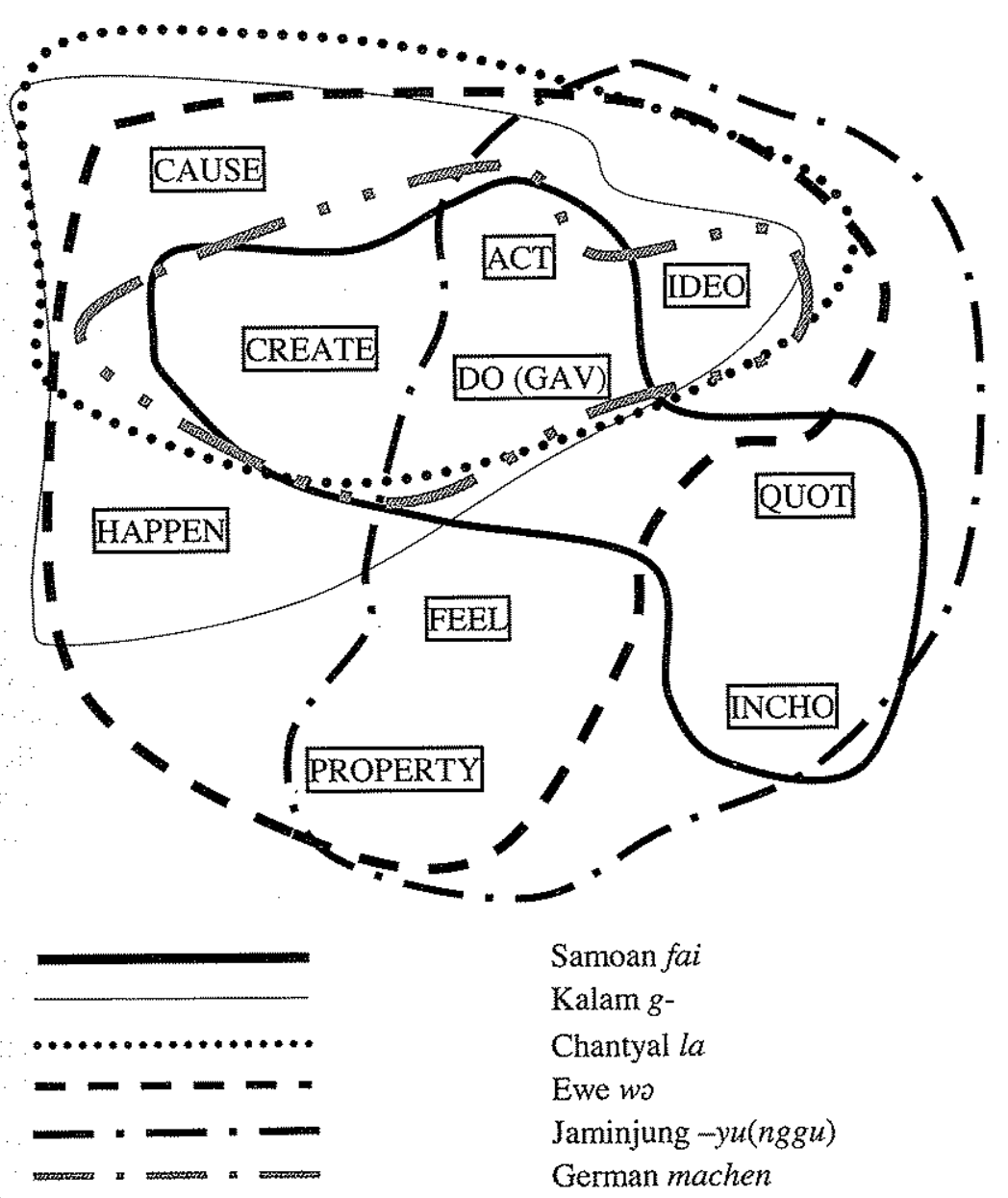

Figure 1. A tentative semantic map of functions of generalised action verbs, representing information on six languages 
Table 2. Functions of generalised action verbs in nine languages*

\begin{tabular}{|c|c|c|c|c|c|c|c|c|c|c|}
\hline & Verb & 哭 & 湈 & 5 & $\begin{array}{l}\text { 䁬 } \\
\end{array}$ & 菏 & 拴 & 㢦 & 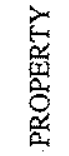 & $\underset{Z}{Z}$ \\
\hline Samoan & $f a i$ & - & $\checkmark$ & $\checkmark$ & $? ?$ & $\checkmark$ & - & + & 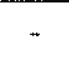 & $\checkmark$ \\
\hline Kalam & $g^{*}$ & $\checkmark$ & $\checkmark$ & $\checkmark$ & $\checkmark *$ & - & $\checkmark$ & - & - & - \\
\hline Yimas & $t \dot{t}$ & - & $\checkmark$ & $? ?$ & $? ?$ & - & $\checkmark$ & $(\checkmark)$ & - & $\checkmark$ \\
\hline Jaminjung & -yunggu & - & - & $\checkmark$ & $\checkmark *$ & $\checkmark$ & . & $\checkmark$ & $(\sqrt{ })$ & $\checkmark$ \\
\hline Ewe & wo & $\checkmark$ & $\checkmark$ & $\checkmark$ & $\checkmark *$ & - & $\checkmark$ & $\checkmark$ & $\checkmark$ & - \\
\hline Hausa & $y i$ & - & $\checkmark$ & $\checkmark$ & $\checkmark *$ & - & $? ?$ & $\checkmark$ & $\checkmark$ & - \\
\hline Kham & jai- & - & $\checkmark$ & $? ?$ & $(\sqrt{ })$ & - & - & - & - & - \\
\hline Chantyal & $l a$ & $\checkmark$ & $\checkmark$ & $\checkmark$ & $\checkmark$ & {$[\sqrt{ }]$} & . & - & - & - \\
\hline German & mach- & - & $\checkmark$ & $(\checkmark)$ & $\checkmark$ & {$[\checkmark]$} & & - & - & - \\
\hline
\end{tabular}

* $\quad$-: function not attested; $\checkmark$ : function attested; $(\checkmark)$ : function attested but appears to be less frequent (in terms of types of collocations); $[\checkmark]$ : specific to QUOT: attested only for nonlinguistic quotation (e.g. "ah"), not for direct speech; $\checkmark *$ : specific to IDEO: sound-symbolic elements may combine with 'do' verb but also with other verbs; ??: not sufficient information.

The uses of 'do' verbs discussed here can be divided into two major categories, agentive (top half of the map) and non-agentive (bottom half of the map). Since the use as GAV ('do what/it') implies agentivity, it is not sur prising that all verbs included in the survey have agentive uses, but not all have non-agentive uses (the latter holds for German, Chantyal, and Kham). The different non-agentive uses - 'HAPPEN', 'FEEL', 'exhibit PROPERTY' and INCHO(ative) - are not very strongly correlated, except for 'FEEL' and 'PROPERTY', represented by closer proximity on the map, since all languages in the sample that have the former also have the latter (except for Yimas, where however the 'FEEL' use seems to be marginal).

As expected on the basis of other cross-linguistic studies, 'do' verbs have a strong affinity with creation verbs (GAVs of eight languages in the sample have both uses, that is all except for Jaminjung) and a somewhat weaker affinity with causation (only three of the nine languages); CAUSE is therefore placed at the margin of the map and next to CREATE to represent the strong semantic link between the two. At least in the sample of lan- guages considered here, all generalised action verbs that are used as causative markers also have the creation sense, and it has been shown elsewhere that causative verbs are frequently derived from creation verbs (Moreno 1993).

The link between quotative and ideophonic uses is not strongly confirmed by the sample - almost all of them use the 'do' verb with soundsymbolic elements (data are insufficient for Samoan and Yimas), but only two of them with quotations (and only one for both); for this reason, QUOT is placed at the margin of the semantic map. In the languages that do not use the 'do' verb, a specific verb of speaking ('say') takes over the quotative function.

On the other hand, the study reveals a strong link between ideophonic uses and uses with agentive activity expressions (co-occurring in at least five or the nine languages). This is not too surprising, because the two often cannot be deliminated, e.g. in languages like Chantyal with a large repertoire of sound-symbolic expressions of manner of motion. However, the IDEO function is not ideally placed on the map as depicted in Figure 1, because sound-symbolic expressions are in fact also frequently employed to represent non-agentive activities such as involuntary internal motion and sound emission; this is the case e.g. in Jaminjung, Chantyal, Kalam, and German.

In any case, the function of verbaliser with sound-symbolic elements turns out to be one of the most frequent functions of 'do' verbs. It may also be a central function in the sense that ' $d o$ ' verbs may or may not entail agentivity, but that they always entail the perceivable manifestation of an event.

\section{Notes}

1. I will leave out of consideration here the case of true interrogative verbs, which appear to be rather rare crosslinguistically (around 10\% of the languages in the sample considered by Idiatov and van der Auwera 2004, who also propose a functional explanation for this observation).

2. The translation equivalent of 'grow, become mature' employs the 'do' verb, not one of the two change-of-state verbs, even in Kalam (Pawley n.d., entry' wos g- 'become mature'). 


\section{References}

"Ameka, Felix K.

1994 Ewe. In Semantic and Lexical Universals, Cliff Goddard and Anna Wierzbicka (eds.), 57-86. Amsterdam: Benjamins.

Anderson, Gregory D.S.

2006 Auxiliary Verb Constructions. Oxford: Oxford University Press.

Cohen, David, Marie-Claude Simeone-Senelle, and Martine Vanhove

2001 The grammaticalization of 'say' and 'do'. In Reported discourse: a meeting ground for different linguistic domains, Tom Güldemann and Manfred von Roncador (eds.), 247-251. (Typological Studies in Language 52.) Amsterdam: Benjamins.

Dowty, D. R.

1979 Word meaning and Montague grammar. The semantics of verbs and times in Generative Semantics and in Montague's PTQ. Dordrecht: Reidel Publishing Company.

Essegbey, James K.

1999 Inherent complement verbs revisited: towards an understanding of argument structure in Ewe. Ph. D. diss., University of Leiden.

Foley, William A

1986 The Papuan Languages of New Guinea. Cambridge: Cambridge University Press.

1991 The Yimas Language of New Guinea. Stanford: Stanford University Press.

Foley, Willam A., and Robert D. Van Valin Jr.

1984 Functional Syntax and Universal Grammar. Cambridge: Cambridge University Press.

Güldemann, Tom

2001 Quotative Constructions in African Languages: A Synchronic and Diachronic Survey. Leipzig: Habilitationsschrift, Fakultät für Geschichte, Kunst- und Orientwissenschaften der Univ. Leipzig.

2002 When 'say' is not say: the functional versatility of the Bantu quotative marker ti with special reference to Shona. In Reported Discourse: A Meeting Ground for Different Linguistic Domains, Tom Güldemann and Manfred von Roncador (eds.), 253-287. (Typological Studies in Language 52.) Amsterdam: Benjamins.

Haspelmath, Martin

2003 The geometry of grammatical meaning: semantic maps and crosslinguistic comparison. In The New Psychology of Language, vol. 2, Michael Tomasello (ed.), 211-242. Mahwah/NJ: Erlbaum.
Heine, Bernd

1993 Auxiliaries. Cognitive Forces and Grammaticalisation. Oxford: Oxford University Press.

Heine, Bernd, and Tania Kuteva

2002 World Lexicon of Grammaticalization. Cambridge: Cambridge University Press.

Idiatov, Dmitri, and Johan van der Auwera

2004 On interrogative pro-verbs. In Proceedings of the Workshop on the Syntax, Semantics and Pragmatics of Questions, 1. Comorovski and M. Krifka (eds.), 17-23. 16th European Summer School in Logic, Language, and Information (ESSLLI).

Jäger, Andreas

2004 The cross-linguistic function of obligatory 'do'-periphrasis. In Proceedings of the 2004 Conference of the Australian Linguistic Society, Ilana Mushin (ed.). http://hdl.handle.net/2123/11

2006 Typology of Periphrastic 'do'-Constructions. Bochum: Brockmeyer. Jaggar, Philip J

2001 Hausa. Amsterdam: Benjamins.

Kuteva, Tania

2001 Auxiliation: An Enquiry into the Nature of Grammaticalization. New York and Oxford: Oxford University Press.

Langdon, Margaret

1977 Semantics and syntax of expressive "say" constructions in Yuman Berkeley Linguistic Society 3: 1-11.

Lehmann, Christian

1995 Thoughts on Grammaticalization. München/Newcastle: Lincom Europa.

Levin, Beth, and Malka Rappaport Hovav

1994 A preliminary analysis of causative verbs in English. Lingua 94: 35-

1995 Unaccusativity: At the Syntax-Lexical Semantics Interface. Cambridge, MA: MIT press.

McGregor, William

1994 The grammar of reported speech and thought in Gooniyandi. Australian Journal of Linguistics 14 (1): 63-92.

Moravscik, Edith

1975 Borrowed verbs. Wiener Linguistische Gazette 8: 3-30.

Moreno, Juan Carlos

1993 'Make' and the semantic origins of causativity: a typological study. In Causatives and Transitivity, Bernard Comrie and Maria Polinsky (eds.), 155-164. Amsterdam: Benjamins. 
Mosel, Ulrike

1994 Samoan. In Semantic and Lexical Universals, Cliff Goddard and Anna Wierzbicka (eds.), 331-360. Amsterdam: Benjamins.

Mosel, Ulrike, and Even Hovdhaugen

1992 Samoan Reference Grammar. Oslo: Scandinavian University Press. Muysken, Peter

2002 Bilingual Speech: A Typology of Code-mixing. Cambridge: Cambridge University Press.

Newman, Paul

2000 The Hausa Language: An Encyclopedic Reference Grammar. New Haven: Yale University Press.

Noonan, Michael

1999 Chantyal Dictionary and Texts. Berlin: Mouton de Gruyter.

2001 The Chantyal language. In The Sino-Tibetan Languages, Graham Thurgood and Randy LaPolla (eds.), 315-335. London: Curzon Press.

Noonan, Michael, and Karen Grunow-Harsta

2002 Posture verbs in two Tibeto-Burman languages of Nepal. In The Linguistics of Sitting, Standing, and Lying, John Newman (ed.), 79101. Amsterdam: Benjamins.

Pawley, Andrew

1993 A language that defies description by ordinary means. In The role of Theory in Language Description, William A. Foley (ed.), 87-129 (Trends in Linguistics. Studies and Monographs 69). Berlin: Mouton.

1994 Kalam Exponents of lexical and semantic primitives. In Semantic and Lexical Universals, Cliff Goddard and Anna Wierzbicka (eds.), 387-422. Amsterdam: Benjamins.

n.d. Kalam Dictionary. Manuscript, Australian National University, Canberra.

Rumsey, Alan

1990 Wording, Meaning, and Linguistic Ideology. American Anthropologist $92: 346-361$

1994 On the Transitivity of 'Say' Constructions in Bunuba. Australian Journal of Linguistics 14: 137-153.

Samarin, William.

1971 Survey of Bantu ideophones. African Language Studies 12: 130168.

\section{Schultze-Berndt, Eva}

$2000 \quad$ Simple and complex verbs in Jaminjung. A study of event categorisation in an Australian language. Nijmegen: Ph. D. diss., Katholieke Universiteit Nijmegen.
Van der Auwera, Johan

1999 Periphrastic 'Do': Typological Prolegomena. In Thinking English Grammar, Guy A. J. Tops, Betty Devriendt, and Steven Geukens (eds.). Louvain: Peeters.

Van der Auwera, Johan, and Inge Genee

2002 English do: On the convergence of languages and linguists. English Language and Linguistics 6 (2): 283-307.

Van der Auwera, Johan, and Ceyhan Temürcü

2006 "Semantic maps in Typology", In Encyclopedia of Language and Linguistics, vol. 11, Keith Brown (ed.), 131-134. Oxford: Elsevier

Van der Auwera, Johan, and Vladimir Plungian

1998 Modality's semantic map. Linguistic Typology 2: 79-124.

Van Valin, Robert D., and Randy J. LaPolla

1997 Syntax: Structure, Meaning and Function. Cambridge: Cambridge University Press.

Watters, David E

2002 A Grammar of Kham. Cambridge: Cambridge University Press.

Wichmann, Søren, and Jan Wohlgemuth

2005 Loan verbs in a typological perspective. To appear in Aspects of Language Contact: New Theoretical, Methodological and Empirical Findings with Special Focus on Romanisation Processes, Thomas Stolz, Dik Bakker, and Rosa Palomo (eds.). Berlin: Mouton de Gruyter. 